\title{
Coalition inclusion probabilities: a party-strategic measure for predicting policy and politics ${ }^{\dagger}$
}

\author{
Mark A. Kayser ${ }^{1 \star}$ (D), Matthias Orlowski ${ }^{2}$ and Jochen Rehmert ${ }^{3}$ \\ ${ }^{1}$ Hertie School, Berlin, Germany, ${ }^{2}$ neuraum Ventures, GmbH, Berlin, Germany and ${ }^{3}$ University of Zurich, Zurich, \\ Switzerland \\ *Corresponding author. Email: kayser@hertie-school.org
}

(Received 28 April 2020; revised 30 March 2021; accepted 14 September 2021; first published online 20 January 2022)

\begin{abstract}
Policy in coalition governments (a) depends on negotiations between parties that (b) continue between elections. No extant means of predicting policy-bargaining power indices, vote shares, seat shares, polling, veto players or measures of electoral competitiveness-recognizes both of these facts. We conceptualize, estimate and validate the first dynamic measure of parties' bargaining leverage intended to predict policy and politics. We argue that those parties with the greatest leverage in policy negotiations are those with the highest probability of participating in an alternative government, were one to form. Combining a large set of political polls and an empirical coalition formation model developed with out-of-sample testing, we estimate coalition inclusion probabilities for parties in a sample of 21 parliamentary democracies at a monthly frequency over four decades. Applications to government spending and to the stringency of environmental policy show leverage from coalition inclusion probabilities to be strongly predictive while the primary alternatives-vote shares, seat shares and polls-are not.
\end{abstract}

Keywords: coalition bargaining; coalition leverage; policy-making; representation

\section{Introduction}

How do parties translate public preferences into policy in multiparty systems? The link between public preferences and government actions lies at the heart of democratic governance, leading generations of scholars to investigate questions of policy representation and responsiveness. A large majority of this research, however, focuses on countries characterized by single-party governments, such as the United States, the United Kingdom and Canada. ${ }^{1,2}$ In coalition governments, public opinion also influences parties' policy preferences but the implementation of any coalition member's preferences into actual policy requires an extra step: coalition bargaining.

Until now, no strategically oriented, dynamic and empirically validated means of predicting which party's preferences will emerge as policy has existed. Some scholars, of course, have nonetheless analyzed the influence of public preferences and policy outputs in multiparty systems (e.g., Klemmensen and Hobolt, 2005; Wlezien and Soroka, 2012) but they have done so by neglecting

\footnotetext{
${ }^{\dagger}$ Previously presented at the ECPR 2016 Joint Sessions, Pisa, MPSA 2017, EPSA 2018, APSA 2019, Stanford University (TEC) and the University of British Columbia.

${ }^{1}$ See Wlezien and Soroka (2016) for a review.

${ }^{2}$ Other factors include data availability, language barriers and the focus of many European researchers on the particulars of European Union policy-making.

(c) The Author(s), 2022. Published by Cambridge University Press on behalf of the European Political Science Association. This is an Open Access article, distributed under the terms of the Creative Commons Attribution-NonCommercial-NoDerivatives licence (https://creativecommons.org/licenses/by-nc-nd/4.0/), which permits non-commercial re-use, distribution, and reproduction in any medium, provided the original work is unaltered and is properly cited. The written permission of Cambridge University Press must be obtained for commercial re-use or in order to create a derivative work.
} 
the policy bargaining stage. Scholars wishing to acknowledge that parties' policy preferences do not translate directly into policy outputs in multiparty governments had only two choices: they could (1) turn to static measures such as seat allocation rules (e.g., Gamson, 1961) and/or bargaining power indices (Shapley and Shubik, 1954; Banzhaf, 1964) or (2) posit that parties' standing in the polls or shifts in public opinion on specific issues over time alter the balance of power in coalition governments (e.g., Lupia and Strøm, 1995).

We draw on key insights from both of these approaches to develop a novel measure of bargaining leverage in coalition governments. Like Shapley and Shubik (1954), we argue that bargaining leverage arises from credible threats to quit the government and, like Lupia and Strøm (1995), we argue that the credibility of such threats varies dynamically over the life of a government as external circumstances and polls change. We differ, however, by arguing (and demonstrating) that most shifts in party polling and public opinion are not sufficient to change bargaining outcomes and, hence, policy. Shifts in polling only change bargaining leverage and policy outcomes when they also change a party's ability to participate in an alternative government. Thus, what matters in dynamic negotiations over policy in coalitions is how changes in external polls affect parties' probabilities of inclusion in alternative governments: coalition inclusion probabilities.

We also differ from these theoretical literatures in our empirical focus. We build an empirical coalition formation model that we optimize for prediction with out-of-sample testing and then apply to a large sample of polls. We can thus predict the probability of every possible coalition that could form at each point in time and then sum by party to calculate the probability of each party entering government. Numerous variants of coalition inclusion probabilities (CIPs) are possible, depending on the application and whether one wishes to calculate, say, a given party's leverage vis-à-vis a specific bargaining partner by calculating the probability of the first party entering a government that excludes the second. The project described in this paper calculates a set of CIPs for most parties in 21 parliamentary democracies at a monthly frequency for all periods in which data exist between 1970 and 2018.

Consequently, we make publicly available a set of measures that, in combination with other variables, should enable scholars to better predict party behavior and policy outcomes in multiparty governments. We demonstrate our measures' utility with two distinctly different applications-government spending and the stringency of environmental policies-and contrast the performance of CIPs with weak results from naïve alternatives that neglect coalition bargaining: political polls, seat shares and public opinion.

\section{How to predict policy}

\subsection{Public opinion}

Scholars have made large strides explaining and predicting policy in settings with single-party governments. Research on the United States, United Kingdom and Canada has shown that public preferences on issues generally cluster across issues, suggesting a single underlying preference for government action (Stimson et al., 1995) but also that some salient issues can deviate and influence policy (Druckman and Jacobs, 2006), that policy mood responds to the economy (Durr, 1993), that policy change often precedes changes in public opinion (Page and Shapiro, 1983), that governments shift policy dynamically in response to public opinion between elections (Stimson et al., 1995), and that policy and public opinion interact "thermostatically" with each influencing the other (Wlezien, 1995; Soroka and Wlezien, 2010).

Research that addresses multi-party systems, however, has yielded notably fewer and less precise findings predicting policy outcomes. We do know how broad policy outcomes differ in systems with single-party and multi-party governance-policy responsiveness is slower (Wlezien and Soroka, 2012) in many of the countries in which policy changes come in infrequent but 
large clusters (Baumgartner et al., 2009) - but more fine-grained questions about which party successfully implements its preferred policy and in what circumstances elude us.

So, why does policy research do so much better in single-party government settings? The reason, we argue, is that predicting policy from coalition governments requires understanding the bargaining leverage of the parties, a step that is not necessary with single-party majority governments. Interestingly, one important and highly visible finding that does address policy outcomes in multiparty systems posits coalition negotiations and compromise as the reason why policy outcomes in coalition governments hew closer to the public opinion preferences of the median voter in proportional than in majoritarian electoral systems (Huber and Powell, 1994; Powell, 2009). What they do not address, however, is how coalition members reach a compromise. It is precisely this process and how it influences policy in favor of which actors that we seek to address here theoretically but, most importantly, through the creation of a new tool.

\subsection{Elections and polls}

Electoral competitiveness, like public opinion, also serves frequently as a predictor of policy. In contrast to public opinion that usually concerns a particular issue, however, electoral competitiveness is most often associated with how well, closely or quickly governments respond to a valence issue or shift policy toward the preferences of the greatest number of voters. Politicians elected in competitive settings, for example, purportedly respond more to their median constituents (Ansolabehere et al., 2001), moderate their partisan preferences in fiscal policy (Solé-Ollé, 2006) and spend more on public goods (Hecock, 2006).

Measuring electoral competitiveness, however, is not so straight-forward. The strong overrepresentation of single-country studies in research related to electoral competitiveness, most notably the United States and other countries with frequent single-party government, is likely a result of the ease of measuring competitiveness with two-party vote-, poll- or seat-margins in such systems. ${ }^{3}$ The dependence of such margins on the number of parties in the system makes it an awkward measure for cross-national samples that include multiparty systems. Given that a minority of developed democracies host two-party systems, cross-national research requires a measure of electoral competitiveness that also captures patterns of party competition in multi-party systems.

Recently, a few cross-national measures have emerged, each presenting a distinct way of conceptualizing and measuring multi-party electoral competitiveness as electoral vulnerability (Abou-Chadi and Immergut, 2014), the probability of the party with the most seats in parliament losing its plurality (Kayser and Lindstädt, 2015), bargaining power categories (Abou-Chadi and Orlowski, 2016) and electoral availability (Wagner, 2017). Electoral competitiveness may indeed influence parties' policy positions but predicting party positions is not the same thing as predicting policy. Regardless of how well electoral competitiveness predicts parties' policy positions, even in multiparty systems (see, e.g., Adams, 2012), it does not and cannot address the fact that policy outcomes in most coalition governments are the outcome of coalition bargaining rather than the preferences of any single party. In other words, an intervening and crucial step-coalition bargaining-exists between electoral competitiveness (usually based on vote, seat or polling outcomes) and policy in multiparty systems with coalition governments.

Nor can one simply assume that increases in vote, seat or poll shares will map monotonically onto the probability of a party advancing its preferred policy. For example, one strong factor influencing policy is inclusion in government but simply increasing vote and seat share will not necessarily increase a party's chance of gaining office. A party that shifts from the third to the second largest seat share in a parliament, for example, might actually reduce its probability of government inclusion because the largest party might, following Gamson's law, prefer the

\footnotetext{
${ }^{3}$ Kayser and Lindstädt (2015), for example, find that 21 of 29 articles related to electoral competitiveness in three top political science journals in a five-year window focus on a single-country.
} 
third largest party as a coalition partner in order to dole out fewer portfolios. What matters for predicting policy and parties' behavior, we argue, is often not polls, vote shares, seat shares, measures of electoral competitiveness or even public opinion but the specific set of coalition formation options and bargaining leverage that parties hold.

\subsection{Bargaining power and policy positioning}

In coalition governments, bargaining between coalition members determines policy while future coalition opportunities partly determine parties' preferred party positions. Thus, both current coalition conditions (via bargaining leverage) and future coalition prospects (via strategic policy positioning) influence policy.

\subsubsection{Bargaining leverage}

When multiple parties with differing policy preferences are in government, bargaining leverage matters for policy-making. When a party can credibly threaten to abandon the government for an alternative governing coalition, especially one that excludes the leading party, it has considerable influence. This assertion is not novel. Over half a century ago, the authors of several voting power indices generated algorithms to calculate the power (weight) of each vote (party) as a function of its probability of causing a coalition to form or fail by switching (Penrose, 1946; Shapley and Shubik, 1954; Banzhaf, 1964). Exit threat is the key idea of voting power indices (e.g., Banzhaf, 1964) and outside options are key to coalition members' leverage (Becher and Christiansen, 2015). Voting power indices and work on bargaining weights remained mostly theoretical, however, because they omitted key constructs such as party ideology that empirically matter for coalition formation.

But can parties credibly bargain over policy in the first place? The outcome of bargaining in early models of coalition formation was primarily portfolio allocation rather than policies. An early and seminal model of coalition formation posits that informational and agenda setting advantages turn ministers into "policy dictators" in the portfolio of their ministries (Austen-Smith and Banks, 1990; Laver and Shepsle, 1996). Thus, credible policy compromise between parties is not possible, only compromise about which party controls which ministry. Policy-making in these approaches boils down to a collection of the ideal points of the parties holding given portfolios.

Later research, however, highlights the role of institutions in policing the coalition bargain (for a review, see Martin and Vanberg, 2015). Parties, in this approach-most recently articulated by Martin and Vanberg (2020) in the framework of bargaining along a contract curve-are able to reach policy compromises in which parties holding a portfolio agree to a policy position deviating from their ideal point. Policing by junior ministers (e.g., Thies, 2001), legislative review (Kim and Loewenberg, 2005; Martin and Vanberg, 2011) and coalition agreements (Klüver and Bäck, 2019) can ensure that legislative drafts coming from ministries adhere to the bargain despite the temptation of "ministerial drift."

\subsubsection{Dynamic bargaining and strategic positioning}

Policy compromises, regardless of how they are codified and enforced, are not set in stone. Policy outcomes can differ considerably from what was originally agreed following an election, for example, for the simple reason that circumstances change. Lupia and Strøm (1995, e.g., p. 649), on whose argument we build, posit that bargaining in coalitions over the life of a government is influenced by changes in parties' standings in the polls: “The anticipation of good electoral fortunes gives a party a bargaining chip that it can exploit by either negotiating the balance of power within an existing coalition, forging a more attractive coalition with new partners, forcing dissolution and new elections, or protecting the existing cabinet." What we add, however, is the contention that parties' leverage does not rely on anticipated electoral performance (polls) 
but, more specifically, on how such an electoral performance would translate into coalition options. Such changes in coalition leverage can then be converted into policy changes without, as Martin and Vanberg (2020) note, the formal rebalancing of power in a coalition.

We adhere to this understanding of coalition formation, bargaining leverage and crossportfolio policy compromise. We also extend it in two ways that speak to the primary theoretical contribution of this paper, the argument that parties' CIPs predict policy. First, we posit that bargaining leverage in the form of coalition inclusion probabilities (exit threat) but also calculations about parties' policy positions for their future coalition options (strategic positioning) affect policy outcomes. A party may benefit from adopting a policy position in a portfolio that it holds that deviates from its ideal point if that position is likely to offer it more or better coalition options whenever the next government is formed. Second, while previous research has investigated how parties form coalitions and coalition agreements, we introduce a dynamic understanding of parties over the life of a coalition that seeks to explain when parties, in response to polling information and forward-looking coalition calculations, break coalition agreements by demanding a new or revised policy.

\subsection{Why CIPs matter}

So, why do we need coalition probabilities to measure bargaining leverage? Why not capture leverage by employing expected seat shares which, in PR systems, map closely to expected vote shares and polls, to capture leverage? We have already noted that vote and seat shares are poor predictors of policy because they neglect policy bargaining in coalition governments, but could they themselves not serve as a measure of bargaining leverage? One might expect a party to have stronger outside options and, hence, a more credible exit threat if its polling numbers are strong. Political polling, in addition, is conducted regularly over the term of governments in most developed democracies, so could offer a dynamic measure of parties' strength. Seat shares, of course, map closely to vote shares in PR systems.

Our answer, in short, is that inclusion in government plays a critical role in most parties' objective functions and seat shares do not map smoothly onto the probability of parties being included in government. We illustrate this point with a simplified theoretical example that shows the relationship between seat shares and coalition inclusion. Figure 1 plots the probability of each of three parties being included in government as a function of the seat share of the first party (Party A). ${ }^{4}$ Two observations from the figure are critical to our argument that coalition inclusion probabilities, not expected seat shares, should matter for bargaining leverage if parties seek participation in government. First, coalition inclusion probability is not a continuous function of seat share and is not necessarily monotonically related to seat share. Second, a party's vote share (and, hence seat share) can vary considerably within certain ranges without changing its coalition prospects at all. At given points, however, CIP jumps up (or down) to a new value. Seat shares, therefore, are a poor guide to predicting parties' behavior even if expected seat share is conceived of as a measure of bargaining leverage. The results that we show later in this article that CIPs, but not seat shares, predict policy can thus be interpreted as evidence that parties care more about inclusion in government than seat shares, per se.

\subsubsection{An illustration: the German government of 2009-2013}

The influence of coalition inclusion prospects on party behavior is not only a theoretical matter. Before addressing empirical estimation in the following section, we illustrate here how changing

\footnotetext{
${ }^{4} \mathrm{We}$ assume four rules: majority parties always form single-party governments; the plurality party is always the formateur; invited parties always accept; and no surplus coalitions. Four parameters govern the distribution of seat shares, which we assume are equal to vote shares, and coalition invitations: Party B receives 0.7 of the seats that do not go to Party A; Party A prefers Party B 0.7; Party B prefers Party A 0.6; and Party C prefers Party A 0.2 .
} 


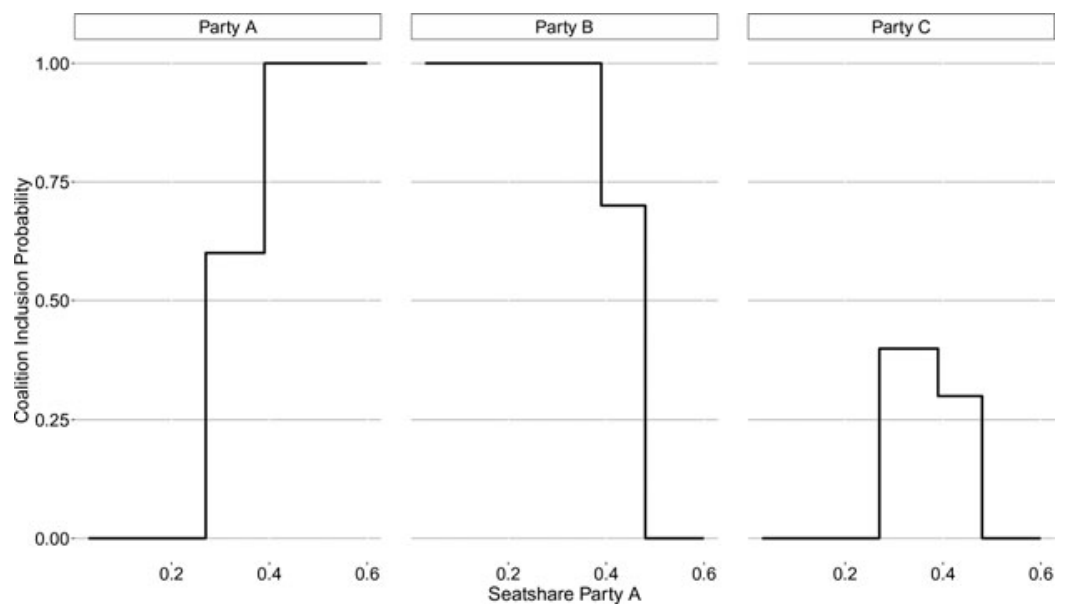

Fig. 1. Theory-CIP versus vote shares. Coalition probabilities plotted against Party A's seat share. Note that CIPs are not a continuous function and are not necessarily monotonic.

coalition calculations can influence party position taking and governmental policy outcomes via both exit threat and strategic positioning with an example from one government in Germany.

After their victory in the 2009 election, the German Christian Democratic Party (CDU) and their Bavarian sister party, the Christian Social Union (CSU), chose to form a government with the resurgent Free Democratic Party (FDP), which had just achieved an unusually high 15 percent of the seats in parliament. After losing support while serving as the junior partner in the previous government, the Social Democratic Party (SPD) was averse to (re)joining government and the Green Party (10.9 percent) had too small a seat share to form an alternative majority government with the CDU/CSU (38.4 percent).

The FDP's blatant pandering to special interests combined with internal party and coalition friction cost the government considerable support in the polls. After a year in government, the FDP's expected vote share dropped from 14.6 to 5 percent, the minimum necessary for a party to enter the Bundestag. Over the same period, vote intention polling showed the Greens rising from 10.9 to 18 percent, more than enough to become a viable alternative coalition partner for the CDU/CSU. Because we recalculate our CIP measure monthly with new vote intention polling data, it captures such changes in coalition options. The CDU/CSU, we argue, was also keenly aware of these changes which reduced the policy leverage of the FDP dramatically while increasing that of the Greens.

Here, we see examples of both of our mechanisms. The CDU/CDU, despite being only half way into the expected duration of their coalition government with the FDP, pushed through an abrupt policy change anathema to their business-friendly junior coalition partner, announcing an accelerated country-wide phase-out from nuclear power.

The government had already concluded a nuclear phase-out agreement with industry stakeholders but by breaking this agreement and pushing through an accelerated time-table, the $\mathrm{CDU} / \mathrm{CSU}$ strategically positioned themselves as viable coalition partners for the Greens in future elections. This is an example of strategic positioning. It is also an example of exit threat: the FDP could do little to stop this policy change because the CDU/CSU enjoyed a very credible exit threat of forming a new government that excluded them in favor of the Greens, while the FDP had little chance of inclusion of an alternative government.

Polling changes and policy-making in this one government neatly illustrate both mechanisms at work. The dynamic construction of our CIP measure allows it to predict policy change, as a consequence of changing coalition geometries, between elections. 


\section{Empirical overview}

\subsection{Empirical strategy}

To estimate CIPs, we fit an optimal model of coalition formation using election results and then replace vote shares with monthly polling averages to predict coalition probabilities and, consequently, CIPs. More specifically, we follow a three-step procedure: (1) selecting the key predictors of coalition formation by benchmarking against the state-of-the art empirical models in the literature, (2) expanding the coalition formation data to include situations in which one party gains a majority in parliament, adjusting the model and then, (3) running this model on a greatly expanded dataset that extends up to 2018 and adds many democracies, most notably in Central and Eastern Europe. In this last step, we employ monthly polling averages as if they were elections, predicting the probability of every possible government that could form. The sum of the probabilities of all potential governments that include a given party is the CIP of that party.

With applications to government spending and environmental policy, we demonstrate the comparative usefulness of CIPs relative to polls-the main alternative measure of party fortunes that varies between elections, but one that does not capture the coalition calculus of parties.

\subsection{Data and variables}

Our endeavor relies on two datasets: one containing information on the party composition of governments and legislatures in 31 parliamentary democracies ${ }^{5}$ between 1947 and 2018 and one containing aggregates of different monthly polls since 1970 in 21 countries. $^{6}$ We draw on data on parliaments and governments provided by Döring and Manow (2016) and on parties' ideological position (Volkens et al., 2015) ${ }^{7}$ to assemble the first. Jennings and Wlezien (2016) collected the original polling data for the second, which we then augmented and extended (see the list of alternative sources in online Appendix C). Our end result is CIPs for the parties in the 21 parliamentary democracies and in the periods listed in Table $1 .^{8}$

Our dataset for the first step-choosing the best model of government formation-contains 116,484 potential cabinets that could have formed in 454 different formation opportunities, that is, either post-election or post-cabinet termination bargaining situations as defined by Martin and Stevenson (2001). ${ }^{9}$ To support out-of-sample testing, we randomly select and set aside approximately 20 percent of our sample of formation opportunities in which no single party had a majority (i.e., 18,100 potential cabinets in 62 formation opportunities). This leaves us with 79,084 observations in 262 formation opportunities in a training set for step 1 .

Details on the operationalization of the variables are presented in the online appendix (Section A) and in the replication materials.

\section{Model estimation}

\subsection{Step 1: selection of predictors}

Our first step is to select a model that performs as well as possible in and out-of-sample. We model the probability of exactly one potential cabinet forming out of all possible cabinets

\footnotetext{
${ }^{5}$ Australia, Austria, Belgium, Canada, Denmark, Finland, Germany, Greece, Iceland, Ireland, Italy, Japan, Luxembourg, the Netherlands, New Zealand, Norway, Portugal, Spain, Sweden, and the United Kingdom, as well as Bulgaria, Croatia, the Czech Republic, Estonia, Hungary, Latvia, Lithuania, Poland, Romania, Slovakia and Slovenia.

${ }^{6}$ Austria, Czech Republic, Denmark, Estonia, Finland, Germany, Greece, Hungary, Iceland, Ireland, Italy, Japan, the Netherlands, New Zealand (post-1996), Norway, Poland, Portugal, Slovakia, Slovenia, Spain and Sweden.

${ }^{7}$ More specifically, we compute parties' log RILE-scores as detailed in Lowe et al. (2011).

${ }^{8} \mathrm{We}$ also provide static CIPs for all parliamentary parties in 31 countries from the 1950s to today as used in our estimation model, which amounts to 46,894 observations.

${ }^{9}$ We excluded formation opportunities where caretaker governments took office as well as those where we lack information on important covariates for parties that together held more than 5 percent of legislative seats. In all other cases, we deleted parties with missing information from a formation opportunity before computing the corresponding potential cabinets.
} 
Table 1. Coverage of CIP estimates

\begin{tabular}{|c|c|c|}
\hline Country & Period & Parties \\
\hline Austria & $1995,1997,1999-2018$ & BZÖ, Dinkhauser, FPÖ, Greens, LIF, NEOS, ÖVP, PILZ, SPÖ, Stronach \\
\hline Czech Republic & $1993-2018$ & $\begin{array}{l}\text { ANO, CSSD, KDU-CSL, KSCM, LSU, ODA, ODS } \\
\text { Pi, SPD, SPR-RSC, STAN, SZ, TOP09, UPD, US, WV }\end{array}$ \\
\hline Denmark & $1970-2018$ & A, CD, DF, DKP, En-O, FK, FrP, KF, KrF, NLA, RF, RV, Sd, SF, V, VS \\
\hline Estonia & $2007-2018$ & EER, EK, ERa, ERe, EV, IRL, SDE|M \\
\hline Finland & $1994-2018$ & DL|VAS, KESK, KOK, RKP-SFP, Rt, SKL|KD, SP|P, SSDP, UV, VIHR \\
\hline Germany & 1970-2018 & AfD, CDU|CSU, FDP, Greens, PDS|Linke, SPD \\
\hline Greece & $\begin{array}{l}\text { 1994-1995, 2007, 2009- } \\
\quad 2018\end{array}$ & $\begin{array}{l}\text { AE, Dimar, DISY, EK, KKE, LAOS, LE, LS-CA } \\
\text { ND, PASOK, POLAN, SYN, SYRIZA, TP }\end{array}$ \\
\hline Hungary & $2000-2018$ & Fidesz, DK, Eygyutt, FKgP, Jobbik, LMP, MDF, MIEP, MSZP, SzDSz \\
\hline Iceland & $1994-2018$ & A, Ab, BF, B-H, Dawn, F, Ff, Graen, HG, IDP, KL, M, Pi, Rebo, Sam, Sj, Th-Ff, V \\
\hline Ireland & 1974-2018 & DLP, FF, FG, Green, IA, Lab, PD, SF, United Left \\
\hline Italy & $2000-2018$ & $\begin{array}{l}\text { AN, CD, Fdl-CN, FdV, FI, IdV, IET, LeU, LN, M5S, MAIE, NCD } \\
\text { Ncl, PD, PdCl, PdL, PoUD, PRC, RI, SC, SEL, SVP, UDC, USEI }\end{array}$ \\
\hline Japan & $1998-2018$ & CGP, DPJ, JCP, JReP, CDP, LDP, LP, PH, SDP, YP \\
\hline Netherlands & $1970-2018$ & $\begin{array}{l}50+, \text { ARP, CDA, CHU, CU, D66, DENK, DS70, FVD } \\
\text { GL, KVP, LN, LPF, PvdA, PvdD, PVV, SGP, SP, VVD }\end{array}$ \\
\hline New Zealand & $1996-2018$ & A, ACT, Greens, LP, Mana, MP, NP, NZFP, PP, UFNZ \\
\hline Norway & 1970-2018 & DLF, DNA, Fr, H, KrF, MDG, RV, SF, Sp, SV, V \\
\hline Poland & 1993-2018 & $\begin{array}{l}\mathrm{D}|\mathrm{W}| \mathrm{U}, \mathrm{AWS}, \mathrm{BBWR}, \mathrm{ChD}, \mathrm{K}, \mathrm{KLD}, \mathrm{Korwin}, \mathrm{KPN}, \mathrm{LPR}, \mathrm{N}, \mathrm{NCDBdP}, \mathrm{NSZZ} \\
\mathrm{PC}, \mathrm{PiS}, \mathrm{PL}, \mathrm{PO}, \mathrm{PSL}, \mathrm{Razem}, \mathrm{RdR}, \mathrm{ROP}, \mathrm{RP}, \mathrm{SDPL}, \mathrm{SRP}, \mathrm{UP}, \mathrm{UPR}, \mathrm{X}, \mathrm{ZChN}\end{array}$ \\
\hline Portugal & $1985-2018$ & BE, CDS-PP, CDU, PRD, PS, PSD \\
\hline Slovakia & 2004-2018 & $\begin{array}{l}\text { ANO, HZDS, KDH, KLsNS, KSS, MH, OLANO } \\
\text { S, SaS, SDKU, Smer, SMK-MKP, SNS, SR }\end{array}$ \\
\hline Slovenia & $1996-2018$ & $\begin{array}{l}\text { DeSUS, DL, L, LDS, LMS, LZJ-PS, NSI, SDS, SLS } \\
\text { SMC, SMS, SNS, ZaAB, Zares, ZdLe, ZL-SD, ZS }\end{array}$ \\
\hline Spain & 1980-1982, 1984-2018 & $\begin{array}{l}\text { AP-P, BNG, CC, CDC, CDS, CiU, C-PC, EHB, ERC } \\
\text { P, PCE|IU, PNV, PSOE, UCD, UPyD }\end{array}$ \\
\hline Sweden & 1970-2018 & C, FP, LD, MP, MSP, NyD, SAP, SD, V \\
\hline
\end{tabular}

that could potentially form at a particular formation opportunity using a conditional logit model. Hence, for a legislature containing $p$ parties, we estimate the probability that exactly one of $2^{p}-2$ potential coalitions forms. ${ }^{10}$ In this set-up, the interdependence implied by choosing one government alternative over another is accounted for by treating formation opportunities as the units of analysis and the potential governments as the respective choice sets (Martin and Stevenson, 2001, 2010; Glasgow et al., 2012).

In evaluating hypotheses about coalition formation, it is conventional to exclude formation opportunities in single-party majority legislatures from the data. In order to benchmark our model against previous models in the literature, we initially follow this standard and exclude 130 from our total of 454 formation opportunities in which a single party held an absolute majority of legislative seats. Our final goal, however, is not to evaluate the effect of particular covariates on coalition formation but to derive parties' expected probabilities of entering government, even single-party government, from polls. We therefore reintroduce the majority legislatures in step 2.

Table 2 presents the coefficient estimates of our conditional logit model of coalition formation that was chosen to optimize fit. We based our initial specification on those in Martin and Stevenson $(2001,2010)$ and then changed, omitted and added a number of variables to improve model performance. In a hypothesis testing framework, this would be suspect, but our purpose here is not theory testing, rather model building for optimal prediction. Observations are formation opportunities and all of the potential coalitions in a given formation opportunity constitute the choice set. Although we run our model on largely self-collected data, we rely for some

\footnotetext{
${ }^{10}$ Note that the total number of potential coalitions that could form in a legislature with $p$ parties is in fact $2^{p}-1$. Following the standard approach in the literature, however, we exclude the coalition of all parties as a possibility.
} 
Table 2. Coalition formation, excluding majority situations

\begin{tabular}{|c|c|c|c|}
\hline & \multicolumn{3}{|c|}{$K O R$} \\
\hline & Coeff. & & S.E. \\
\hline Minority government & -0.660 & & $(0.542)$ \\
\hline Minimal winning coalition & $0.486^{\star \star \star}$ & & $(0.155)$ \\
\hline Number of parties in coalition & -0.049 & & $(0.115)$ \\
\hline Largest party in coalition (LP) & $1.078^{\star \star \star}$ & & $(0.298)$ \\
\hline Median party in coalition & $0.537^{\star \star \star}$ & & $(0.190)$ \\
\hline Previous PM party in coalition (PM) & $-0.783^{\star \star}$ & & $(0.377)$ \\
\hline Status quo (SQ) & $1.705^{\star \star \star}$ & & $(0.439)$ \\
\hline Minority government with investiture requirement & $-0.537^{\star}$ & & $(0.300)$ \\
\hline Anti-establishment preference in coalition & -0.923 & & $(1.208)$ \\
\hline Similarity & 0.879 & & $(0.545)$ \\
\hline Intracabinet conflict $\times$ SQ & -0.115 & & $(0.449)$ \\
\hline Intracabinet conflict $\times$ PM & 0.112 & & $(0.407)$ \\
\hline Postelection bargaining $(\mathrm{PE}) \times \mathrm{SQ}$ & 0.613 & & $(0.406)$ \\
\hline Average seat change (SC) & 0.043 & & $(0.050)$ \\
\hline $\mathrm{SC} \times \mathrm{PE}$ & 0.018 & & $(0.059)$ \\
\hline $\mathrm{SC} \times \mathrm{SQ}$ & 0.028 & & $(0.071)$ \\
\hline $\mathrm{SC} \times \mathrm{PE} \times \mathrm{SQ}$ & -0.034 & & $(0.082)$ \\
\hline Anti-system party in coalition & $-2.083^{\star * *}$ & & $(0.352)$ \\
\hline Second largest party & 0.188 & & $(0.221)$ \\
\hline Third largest party & $0.801^{\star \star \star}$ & & $(0.208)$ \\
\hline Cabinet history & $2.590^{\star \star \star}$ & & $(0.514)$ \\
\hline Ideological range in coalition (party families) & $-0.647^{\star \star *}$ & & $(0.091)$ \\
\hline Ideological divisions in majority opposition (party families) & 0.067 & & $(0.103)$ \\
\hline Countries & \multicolumn{3}{|c|}{20} \\
\hline Formation opportunities (in-sample) & \multicolumn{3}{|c|}{262} \\
\hline Observations & \multicolumn{3}{|c|}{79,084} \\
\hline Cox and Snell $R^{2}$ & \multicolumn{3}{|c|}{0.011} \\
\hline Max. possible $R^{2}$ & \multicolumn{3}{|c|}{0.028} \\
\hline Log likelihood & \multicolumn{3}{|c|}{-657.767} \\
\hline
\end{tabular}

Note: Conditional logit with formation opportunities as observations and potential coalitions in choice set. ${ }^{*} p<0.1 ;{ }^{* *} p<0.05 ;{ }^{* \star *} p<0.01$.

covariates on replication data from Martin and Stevenson (2010). In order to allow comparisons on the same data, we restrict the estimation in the first two steps to data with full coverage on all covariates in what is approximately the Martin and Stevenson (2010) sample, (i.e., 20 OECD democracies, 1947-2010).

Our model performs similarly to or slightly better than those of Martin and Stevenson (2001, 2010), as shown in Appendix Table B1, through the inclusion of six new variables. We use a common government experience indicator in place of a familiarity score; our anti-system party indicator, as defined by Abedi (2004), replaces the anti-establishment index based on CMP data (Volkens et al., 2015), because the original variable does not account for how a party's anti-establishment standing is perceived by other parties; and we introduce two new indicators capturing whether a potential coalition contains the second or the third largest party in parliament, as we expect that the coalition inclusion chances of the third largest party, the "kingmaker," trump those of the second largest party. ${ }^{11}$

Finally, we replace the two log RILE measures of ideological distance in the government and the opposition with two based on party family. For this, we take cues from the results of work done by König et al. (2013) whose implications guide us in ordering party families along a latent left-right dimension based on their log RILE scores and assigning integer values increasing by one

\footnotetext{
${ }^{11}$ The largest party, often the formateur, is expected to choose the third largest over the second largest party to maintain a greater Gamson score and hence greater influence in the cabinet. Parties know that once a cabinet is formed, proportionality to seat shares will govern portfolio allocation (Cutler et al., 2016).
} 
moving from left to right. ${ }^{12}$ In this way, we lose variation in parties' ideological positions but we gain a large number of party-election observations. ${ }^{13}$ Moreover, a sequence based on party families still conveys the most important ideological information within each formation opportunity in our conditional logit set-up-who is adjacent to whom-and model performance is nearly identical. ${ }^{14,15}$ At the coalition level, we measure distance simply as the absolute distance between the two most extreme parties of a potential coalition. The data stem from ParlGov (Döring and Manow, 2016) and the CMP (Volkens et al., 2015); for parties in the agrarian party family and for special issue parties, we looked into their international party group affiliation and/or which parliamentary party group they belong to in the European Parliament to approximate their ideological position.

Because the purpose here is not to replicate but to build on previous research to select the best specification for predicting coalition formation, we especially care about out-of-sample prediction. The results suggest that our new variables indeed matter for cabinet formation. Anti-establishment parties fare worse in entering a coalition, while the more frequently a large set of parties within a potential cabinet has recently governed together, the more likely these parties are to eventually form a government. Additionally, being the third largest party in parliament is significantly associated with government formation lending some credibility to the common "kingmaker" analogies. Our party-family based ideology indicator performs roughly as well as the original one based on log RILE scores but with the advantage of a much lower loss of observations in step 3 below.

The Cox and Snell $R^{2}$ values reported in Table 2 provide some indication regarding the in-sample predictive performance of our model. The maximum possible value depends on the model's functional form and is reported in the table as well. The $R^{2}$ value of our model shows that with our additional regressors we explain only roughly 40 percent of the variance that a perfectly predictive conditional logit would have for the data at hand. Yet, our model slightly outperforms the current state-of-the-art specifications (see online Appendix Table B1).

What matters most for our purposes, however, is to predict correctly the formation of governments beyond the data we used to estimate the coefficients. Table 3 displays the confusion matrix for out-of-sample point predictions for the 62 randomly selected formation opportunities which we set aside as a testing set. For each formation opportunity, we predict that the potential government with the highest predicted probability will form. Hence, barring ties, we should obtain exactly 62 positive predictions. The rows of Table 3 depict our predictions, while the columns report potential governments that actually did or did not form. Thus, the downward diagonal of the matrix contains the correct predictions and the upward diagonal reports the false negatives and false positives.

The out-of-sample predictive performance mirrors the modest in-sample performance of our model. Although we only predict about 48 percent of coalition governments correctly, our model still outperforms the competitor models that at best predict 45 percent (see Table B2 in the online appendix). Prima facie, these findings seem to suggest that our understanding of government

\footnotetext{
${ }^{12}$ The rank order is: Communist/Socialist (1), Green/Ecologist (2), Social Democratic (3), Liberal (4), Christian Democratic (5), Conservative (6) and National/Right-wing (7) party families.

${ }^{13}$ In our final estimation data-set used to obtain the coefficients for our CIP, we would lose almost 700,000 observations when using log RILE due to the power rule of calculating the number of potential coalitions (see Appendix Table E2). This is due to missing CMP data on 779 party-election observations across virtually all countries. Moreover, CIP obtained from models using party-family and models using log RILE correlate at 0.95 . Hence, since both indicators generate virtually identical values for our end product we go with the one offering us greater coverage.

${ }^{14}$ Running our KOR Par. model again using log RILE instead of our party family indicator results in the same out-of-sample predictive performance at the party-level when looking at AUC values (both models reach values of 0.89 ).

${ }^{15}$ That party family positions do not change over time, in contrast to log RILE, does not matter because conditional logit effects are estimated within choice sets, i.e., formation opportunities.
} 
Table 3. Coalition-level confusion matrix excluding majority situations

\begin{tabular}{|c|c|c|c|}
\hline & Not realized & & Realized \\
\hline not $\widehat{\text { realized }}$ & $\begin{array}{l}18,006 \\
(0.998)\end{array}$ & & $\begin{array}{l}32 \\
(0.516)\end{array}$ \\
\hline realized & $\begin{array}{l}32 \\
(0.002)\end{array}$ & & $\begin{array}{l}30 \\
(0.484)\end{array}$ \\
\hline Precision & & 0.48 & \\
\hline Recall & & 0.48 & \\
\hline
\end{tabular}

Note: Based on our model reported in Table 2 estimated on a training dataset excluding single-party majority situations and predictions tested out-of-sample. Column percentages in parentheses. Precision = TP/(TP+FP); Recall = TP/P.

formation in non-single-party-majority legislatures remains limited but, as we discuss below, the prediction rate for which parties, in contrast to coalitions, enter government is much higher.

\subsection{Step 2: adjusting for majority situations}

\subsubsection{The KOR_par model}

Having identified the most promising predictors of coalition formation on a sample that excluded single-party majority government formation opportunities, we now adjust our model specification to account for such formation opportunities. For this, we introduce interaction terms to capture the conditional effects of our predictors in situations where a single party holds a parliamentary majority and when it does not. As complex models with many predictors usually perform poorly out of sample, we compensate for interactions by reducing the number of predictors. In the following section, we will combine this model with polling data to calculate CIPs. First, however, we must explain the model.

We, unlike much of the coalition formation literature, are interested in the formation of any type of government, including single-party majority cabinets. In order to get the probabilities of inclusion in government right for all parties, we need to know the probability that the majority party will govern alone. We therefore fit an additional model to a dataset that still matches the coverage of Martin and Stevenson (2010)—we will expand the sample in the next step-but includes formation opportunities in single-party majority situations. As most of our indicators are expected to behave differently under single-party majority and non-majority situations, we introduce interaction effects to account for the predictors' possible diverging effects in these situations. Our model in Table 4 includes the key variables from our model in Table 2, interacted with "no-majority situations", the abreviation for no-single-party-majority situations. The dummy variable for no-majority situations, of course, cannot enter the model outside of an interaction because it does not vary within choice sets. As parsimonious models are less likely to fit noise and predict best out of sample, we counter the additional complexity introduced by the interactions by dropping a number of predictors that can safely be regarded as non-confounders on theoretical grounds, offer little predictive value, and are laborious to collect. In order to assess the predictive quality of this model, we again randomly sampled 80 percent of the formation opportunities, now including majority situations, into a training dataset onto which we fit the model and reserved 20 percent as a testing sample. As it contains only a subset of the set of previous predictors we denote this model KOR_parsimonious or KOR_par.

\subsubsection{Predictive validity of the KOR_par model}

At the coalition level, the KOR parsimonious model (Table 4) outperforms the others, which also have been estimated on the new data, both in- and out-of-sample (see Table D1 in the online appendix). But those are also the wrong metrics for our current purpose. We care, first and foremost, about accurately predicting which parties will be in government, an important distinction 
Table 4. General model of government formation (KOR_Par)

\begin{tabular}{|c|c|c|}
\hline & \multicolumn{2}{|c|}{ KOR Par. } \\
\hline & Coeff. & S.E. \\
\hline Largest party in coalition & $0.744^{\star \star}$ & $(0.299)$ \\
\hline Single-party government & -0.658 & $(0.584)$ \\
\hline Largest party $\times$ Single-party gov't & $3.158^{\star \star \star}$ & $(0.605)$ \\
\hline No-majority situation $\times$ Largest party $\times$ Single-party gov't & $2.828^{\star \star \star}$ & $(0.566)$ \\
\hline No-majority $\times$ Minority government & $-0.928^{\star \star \star}$ & $(0.299)$ \\
\hline No-majority $\times$ Minority gov't $\times$ Investiture vote & $-0.547^{\star}$ & $(0.293)$ \\
\hline No-majority $\times$ Minimal winning coalition & $1.123^{\star \star \star}$ & $(0.264)$ \\
\hline No-majority $\times$ Number of parties in coalition & -0.006 & $(0.119)$ \\
\hline No-majority $\times$ Median party in coalition & $0.445^{\star \star}$ & $(0.185)$ \\
\hline Ideological range in coalition & $-0.610^{\star \star \star}$ & $(0.087)$ \\
\hline Status quo & $2.169^{\star \star \star}$ & $(0.174)$ \\
\hline Anti-establishment party in coalition & $-2.316^{\star \star \star}$ & (0.352) \\
\hline No-majority $\times$ Second largest party & 0.348 & $(0.212)$ \\
\hline No-majority $\times$ Third largest party & $1.001^{\star \star \star}$ & $(0.212)$ \\
\hline Cabinet history & $1.331^{\star \star \star}$ & $(0.476)$ \\
\hline Countries & \multicolumn{2}{|c|}{20} \\
\hline Formation opportunities & \multicolumn{2}{|c|}{352} \\
\hline Observations & \multicolumn{2}{|c|}{81,208} \\
\hline$R^{2}$ & \multicolumn{2}{|c|}{0.016} \\
\hline Max. possible $R^{2}$ & \multicolumn{2}{|c|}{0.032} \\
\hline Log likelihood & \multicolumn{2}{|c|}{-668.841} \\
\hline
\end{tabular}

Note: KOR Parsimonious (KOR_Par) model. Training data. Conditional logit. ${ }^{\star} \mathrm{p}<0.1 ;{ }^{\star \star} \mathrm{p}<0.05 ;{ }^{\star \star \star} \mathrm{p}<0.01$.

from predicting precisely which governments will form. If, for example, our model predicts a given coalition and the true coalition entails the identical composition plus one small surplus party, this is coded at the coalition level as a prediction failure. At the party level, however, all of the predicted parties would be coded as successes and the extra party not predicted by the model would affect only the false-negative rate. Table E1 in the online appendix shows that false positives at the coalition level more often include most of the actual governing parties than predict a fully false coalition.

Most importantly, party-level prediction metrics suggest strong predictive performance. The bottom two rows of Figure 2 present the party-level predictive performance of our KOR (Table 2) and KOR_par (Table 4) models, respectively, both in- and out-of-sample. For comparison, we also include the naïve model and Martin and Stevenson models from 2001 and 2010 from Table B1 in the onlineappendix.

Figure 2 shows that the ROC curve for our parsimonious (KOR_par) model run on the data including the single-party-majority formation opportunities captures 89 percent of the truepositive and false-positive area. Thus, for unknown cases, this model detects the true government participation of actual governing parties 89 percent of the time. While the KOR model performs even slightly better, the other models do not predict outcomes as accurately. We choose the KOR_par model over the KOR model as the basis for predicting CIPs because of its greater parsimony and explicit modeling of the theoretical expectation that key covariates have different effects in majority and non-majority situations.

\subsection{Step 3: calculating dynamic CIPs using polls}

In the previous two steps, we have identified the most promising indicators by comparing our models to the state-of-the-art (step 1) and by adjusting the resulting model to data including both non-majority and single-party majority situations through the inclusion of interaction effects (step 2). Now that we have settled on a single model-Table 4 (KOR_par)—using data 


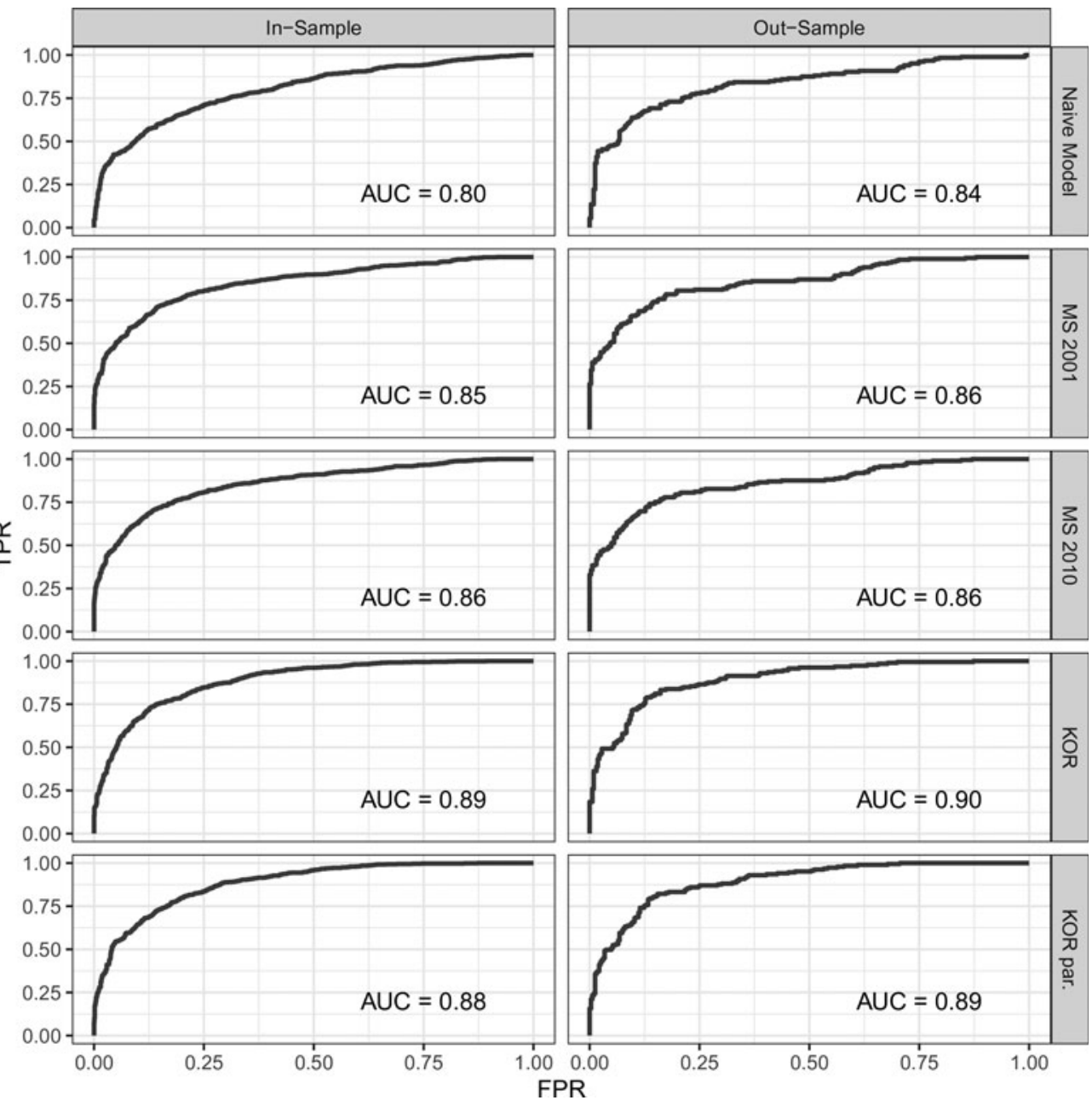

Fig. 2. Party-level ROC plots. Note: All models as specified in Table 2, Table 4 and Appendix Table B1; estimated on samples including single-party majority situations.

that allowed comparison with previous models, we expand our sample to all available government formation opportunities for which we have both coalition formation and polling data. Concretely, this means adding more recent time periods (up to 2018) and more countries (from Central and Eastern Europe). The additional observations, of course, change the coefficients somewhat, as shown in Table E2 in the online appendix. ${ }^{16,17}$

We are now able to calculate the CIPs. By plugging values from polls and other covariates into our KOR_Par coalition formation model, we can predict the probability of all possible coalitions. Note, however, that polls do not enter directly into the KOR_par model, rather they inform several other variables such as the Largest Party, Second Largest Party or Third Largest Party or a

\footnotetext{
${ }^{16}$ We run a separate model for Central and Eastern European countries in which we discard predictors for single-party governments and single-party governments of the largest party to enable convergence.

${ }^{17}$ We test whether each of the final models satisfies the IIA (independence of irrelevant alternatives) assumption by running each 50 times, each time leaving out all potential governments of a formation opportunity for which a random party that will not participate in the government is included. We then compare the coefficients of the full to the restricted model using a Hausman test with Bonferroni correction as suggested by Glasgow et al. (2012). We do not find any IIA violations.
} 
Minority Government or a No-Single-Party-Majority Situation. At each formation opportunity, we can then sum up the predicted probabilities over all potential governments $k$ of which party $q$ is part $(k=j)$ in order to calculate the probability of party $q$ being included in government. More specifically, in its simplest form for any given formation opportunity,

$$
C I P_{q}=\sum_{k=j}^{K} \frac{\mathrm{e}^{\alpha^{\prime} x_{k}}}{\sum_{k} \mathrm{e}^{\alpha^{\prime} x_{k}}}
$$

where $\alpha$ is a vector of coefficients and $x_{k}$ a vector of predictor variables associated with potential government $k$. In essence, the CIP of party $q$ is the sum of the probabilities of all governments that include party $q$. CIPs, of course, can be tailored to match many different bargaining settings. If a researcher, for example, wanted to estimate the bargaining leverage (exit threat) of a junior coalition member on the lead party in a coalition, it is possible to estimate the sum of the probabilities of all possible coalitions that include the junior party and exclude the current lead party. We will make CIP estimates of all such combinations available.

Our polling data include an impressive number of political polls but they are not without gaps and the frequency of polls in different time periods can vary considerably. Both to smooth out noise and to produce coalition inclusion probabilities at regular intervals, we average our polling data by party within months. ${ }^{18}$ Each monthly set of party polling averages is then treated as if it were an election: party poll shares are treated as vote shares which in proportional representation systems approximate seat shares. What matters here is not how well polls predict sometimes distant elections but that politicians interpret them as likely outcomes if an election were to occur at that time. Given that our poll averaging is monthly, our CIP estimates are also monthly.

The result of this exercise is a set of monthly coalition inclusion probabilities for nearly every party in 21 democracies for all years with polling data since 1970 . Not only do we estimate the monthly probability of each party entering government but also, for most parties, their probabilities of entering a government that excludes certain other parties. No previous work known to us has (a) as explicitly theorized a dynamic role for coalition leverage and coalition prospects in policy-making and (b) estimated party-level coalition leverage dynamically between elections. ${ }^{19}$ As politics and policy-making do not stop between elections, there is almost no other measure of party-level policy influence available to researchers that can be used to predict policy change between elections. The only other alternative is polling data which, as we have discussed, neglects party characteristics and the coalition inclusion calculus.

\subsection{Measure validity}

Before we demonstrate the use of our CIP measure in specific applications, it is important to validate it as well as possible. Direct cross-validation is not possible, given that there are no other dynamic measures of credible exit threats, coalition leverage or coalition prospects. However, face validity checks and a test of predictive validity are possible. In the online appendix, we show (1) that the distribution of CIPs for the parties in three distinctly different party systems (Spain, Sweden and Germany) conform to expectations (Section F.1); (2) that CIP values change over time to reflect the different coalition opportunities afforded by small changes in polling over the life of a government (Section F.2); and, for predictive validity, (3) that CIP actually predicts government inclusion (Section F.3).

\footnotetext{
${ }^{18}$ Stochastic uncertainty in the polling data is not a large problem for our purposes for two reasons: (1) we average across all polls within a given month and (2), to be consistent with the approach of the coalition formation models on which we build, polling numbers (that proxy seat shares) enter our calculation only as binary indicators such as largest party in coalition and minority coalition.

${ }^{19}$ For a partial exception, see e.g., Glasgow and Golder (2015).
} 


\section{Applications}

Are CIPs actually useful for predicting policy? To demonstrate the utility of our CIP measure, we provide two brief applications examining government spending and the stringency of environmental policy as a function of certain parties' bargaining leverage. We calculate the yearly mean of parties' monthly CIPs to match the annual frequency of the two dependent variables.

\subsection{Government spending}

Our first application addresses one of the most central functions in a legislature, that is, deciding on government spending. This spending includes delivering public goods and services or providing social protection and is measured as a percentage of GDP. ${ }^{20}$ Whether to spend more or less has been a perennial dimension of political contention in many democracies over time. We model the year-on-year change in government spending as a function of the previous year's GDP growth, the minority status of the government, the time to the next regular election (in years), the number of cabinet parties as well as the ideological range in the cabinet. As discussed above, we are pitting our CIP estimates against polls, as yearly means for both, and seat shares, which only change at elections. We focus on the prime minister's party (PM) and the party holding the finance ministry (FIN). We expect that with greater leverage, that is, CIPs, government parties, especially the PM and the FIN parties, can stave off demands from other government or opposition parties for greater spending and can keep a tighter hold on the budget.

Table 5 reports results from linear models with country and time period fixed-effects and standard errors clustered by country. ${ }^{21}$ The first two models show null findings for the PM and FIN parties' polling support. Similar null findings are shown in the third and fourth models using PM and FIN parties' seat shares. Not only are their coefficients statistically insignificant, but they are nearly zero. In the fifth and sixth models, however, we include the CIPs of the PM and the FIN parties, respectively. As expected, governments tend to spend less compared to the year before when the party holding the finance portfolio sees an increase in its CIP. When the FIN party's CIP moves from 0 to 1 , we would expect a drop in government spending of approximately 1.6 percentage points compared to the year prior. Having a greater probability of inclusion in an alternative government provides the FIN party with greater bargaining leverage over other parties making demands-be they in opposition or coalition partners. For the PM party, the effect has a similarly large coefficient but fails, however, to reach conventional levels of significance. Robustness tests in the appendix show consistent effects of the FIN party when accounting for different measures of the party's ideological position and attitude toward Keynesian demand management (see Table G2 in the online Appendix). Next, we turn to an example exploring how CIPs affect government policy legislation.

\subsection{Environmental policy stringency}

In our final example, we highlight the superiority of CIP over polls and seat shares by modeling a legislative outcome: environmental policy. More specifically, we use environmental policy stringency, a composite measure developed by the Organizaton for Economic Cooperation and Development (OECD) with coverage from the 1990s to 2012, as a dependent variable. This indicator focuses primarily on air and climate policies by covering policies related to environmentally relevant taxes, renewable energy and energy efficiency support, performance standards and information on deposit and refund schemes. It ranges as a continuous measure from 0 to 6 , with 6

\footnotetext{
${ }^{20}$ Data come from the OECD: https://data.oecd.org/gga/general-government-spending.htm.

${ }^{21}$ The sample consists of Austria, Czech Republic, Denmark, Estonia, Finland, Germany, Hungary, Iceland, Ireland, Italy, Japan, Netherlands, Norway, Poland, Portugal, Slovakia, Slovenia, Spain and Sweden for the years 1995 to 2018. Time periods are calculated as five-year periods.
} 
Table 5. Coalition inclusion probabilities and government spending

\begin{tabular}{|c|c|c|c|c|c|c|}
\hline & \multicolumn{6}{|c|}{$\Delta$ Government spending } \\
\hline & \multicolumn{2}{|c|}{ Polls } & \multicolumn{2}{|c|}{ Seat shares } & \multicolumn{2}{|c|}{$\mathrm{CIP}$} \\
\hline & (1) & $(2)$ & (3) & (4) & (5) & (6) \\
\hline 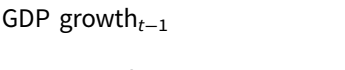 & $\begin{array}{c}-0.087 \\
(0.097)\end{array}$ & $\begin{array}{c}-0.087 \\
(0.096)\end{array}$ & $\begin{array}{r}-0.085 \\
(0.097)\end{array}$ & $\begin{array}{r}-0.096 \\
(0.098)\end{array}$ & $\begin{array}{r}-0.065 \\
(0.089)\end{array}$ & $\begin{array}{c}-0.079 \\
(0.092)\end{array}$ \\
\hline Minority cabinet & $\begin{array}{c}0.217 \\
(0.467)\end{array}$ & $\begin{array}{c}0.192 \\
(0.461)\end{array}$ & $\begin{array}{c}0.257 \\
(0.455)\end{array}$ & $\begin{array}{c}0.110 \\
(0.462)\end{array}$ & $\begin{array}{c}0.040 \\
(0.456)\end{array}$ & $\begin{array}{c}0.089 \\
(0.452)\end{array}$ \\
\hline Time to next regular election & $\begin{array}{c}-0.023 \\
(0.142)\end{array}$ & $\begin{array}{c}-0.022 \\
(0.139)\end{array}$ & $\begin{array}{c}-0.017 \\
(0.140)\end{array}$ & $\begin{array}{r}-0.045 \\
(0.139)\end{array}$ & $\begin{array}{c}0.004 \\
(0.139)\end{array}$ & $\begin{array}{c}-0.020 \\
(0.138)\end{array}$ \\
\hline Number of cabinet parties & $\begin{array}{c}0.306 \\
(0.196)\end{array}$ & $\begin{array}{c}0.249 \\
(0.202)\end{array}$ & $\begin{array}{c}0.334 \\
(0.224)\end{array}$ & $\begin{array}{c}0.175 \\
(0.231)\end{array}$ & $\begin{array}{c}0.077 \\
(0.211)\end{array}$ & $\begin{array}{c}0.090 \\
(0.207)\end{array}$ \\
\hline Ideological range in cabinet & $\begin{array}{r}-0.509 \\
(0.337)\end{array}$ & $\begin{array}{r}-0.543 \\
(0.342)\end{array}$ & $\begin{array}{r}-0.514 \\
(0.333)\end{array}$ & $\begin{array}{r}-0.507 \\
(0.334)\end{array}$ & $\begin{array}{r}-0.572^{\star} \\
(0.341)\end{array}$ & $\begin{array}{r}-0.542 \\
(0.335)\end{array}$ \\
\hline Polls PM (yearly average) & $\begin{array}{c}0.005 \\
(0.027)\end{array}$ & & & & & \\
\hline Polls FIN (yearly average) & & $\begin{array}{c}-0.018 \\
(0.021)\end{array}$ & & & & \\
\hline Seat share PM & & & $\begin{array}{c}0.008 \\
(0.019)\end{array}$ & & & \\
\hline Seat share FIN & & & & $\begin{array}{r}-0.022 \\
(0.017)\end{array}$ & & \\
\hline CIP PM (yearly average) & & & & & $\begin{array}{r}-1.994 \\
(1.306)\end{array}$ & \\
\hline CIP FIN (yearly average) & & & & & & $\begin{array}{c}-1.615^{\star *} \\
(0.808)\end{array}$ \\
\hline Intercept & $\begin{array}{c}-0.456 \\
(1.163)\end{array}$ & $\begin{array}{c}0.487 \\
(0.997)\end{array}$ & $\begin{array}{r}-0.646 \\
(1.048)\end{array}$ & $\begin{array}{c}0.870 \\
(1.027)\end{array}$ & $\begin{array}{c}1.906 \\
(1.483)\end{array}$ & $\begin{array}{c}1.604 \\
(1.071)\end{array}$ \\
\hline Observations & 333 & 334 & 333 & 334 & 333 & 334 \\
\hline Country fixed-effects & $\checkmark$ & $\checkmark$ & $\checkmark$ & $\checkmark$ & $\checkmark$ & $\checkmark$ \\
\hline Period fixed-effects & $\checkmark$ & $\checkmark$ & $\checkmark$ & $\checkmark$ & $\checkmark$ & $\checkmark$ \\
\hline Number of countries & 19 & 19 & 19 & 19 & 19 & 19 \\
\hline$R^{2}$ & 0.033 & 0.036 & 0.033 & 0.036 & 0.048 & 0.050 \\
\hline
\end{tabular}

Note: Observations differ because we include cabinets wit non-partisan PMs. OLS with country and five-year period fixed-effects. Robust standard errors in parentheses. ${ }^{\star} \mathrm{p}<0.1 ;{ }^{\star \star} \mathrm{p}<0.05 ;{ }^{\star \star \star} \mathrm{p}<0.01$.

indicating the most stringent policies (Botta and Kozluk, 2014). ${ }^{22}$ As this indicator is measured annually, we aggregate polls, seat shares and the CIP of parties belonging to the Ecological/Green Party family to the same frequency by calculating means.

Table 6 presents estimates from linear models with country and period fixed-effects. A set of control variables captures economic feasibility and environmental necessity for action-that is, GDP growth and total greenhouse gas emission per capita-while political controls account for political feasibility, preference for reform and public opinion. We control for cabinet status, the ratification of the Kyoto Protocol, the preference for environmental protection measured by item p501 Environmental Protection: Positive of the Manifesto Project (Volkens et al., 2015) and for the share of the population worried about the environment. We measure the cabinet's level of mean environmental protection, that is, the mean of item p501 across all governing parties. Public opinion is measured by the weighted share of respondents per country and year answering strongly agree or agree on the item worry about future environment in three waves (1993, 2000, 2010) of the International Social Survey Programme (ISSP). Data points in between have been linearly interpolated. ${ }^{23}$ Finally, we include a dummy-variable for Green Party government participation.

\footnotetext{
${ }^{22}$ For more information see http://www.oecd.org/economy/greeneco/.

${ }^{23}$ Using a static measure does not significantly change the results.
} 
Table 6. Green parties' influence on environmental policy stringency

\begin{tabular}{|c|c|c|c|c|c|c|}
\hline & \multicolumn{6}{|c|}{ Environmental policy stringency } \\
\hline & $\begin{array}{l}\text { CIP } \\
(1)\end{array}$ & $\begin{array}{l}\text { Polls } \\
\text { (2) }\end{array}$ & $\begin{array}{l}\text { Seat } \\
\text { shares } \\
(3)\end{array}$ & $\begin{array}{l}\text { CIP and } \\
\text { polls } \\
(4)\end{array}$ & $\begin{array}{l}\text { CIP and pub } \\
\text { opinion } \\
\text { (5) }\end{array}$ & $\begin{array}{l}\text { CIP, seat share and } \\
\text { polls } \\
(6)\end{array}$ \\
\hline Minority cabinet & $\begin{array}{c}0.058 \\
(0.083)\end{array}$ & $\begin{array}{c}0.005 \\
(0.083)\end{array}$ & $\begin{array}{c}0.009 \\
(0.081)\end{array}$ & $\begin{array}{c}0.053 \\
(0.080)\end{array}$ & $\begin{array}{c}0.093 \\
(0.103)\end{array}$ & $\begin{array}{c}0.054 \\
(0.080)\end{array}$ \\
\hline Kyoto protocol & $\begin{array}{l}0.160^{\star \star} \\
(0.070)\end{array}$ & $\begin{array}{l}0.178^{\star \star} \\
(0.072)\end{array}$ & $\begin{array}{l}0.193^{\star \star \star} \\
(0.072)\end{array}$ & $\begin{array}{c}0.146^{\star \star} \\
(0.068)\end{array}$ & $\begin{array}{l}0.201^{\star \star \star} \\
(0.074)\end{array}$ & $\begin{array}{l}0.156^{\star \star} \\
(0.068)\end{array}$ \\
\hline Quarterly GDP growth (yearly mean) & $\begin{array}{r}-0.060^{\star} \\
(0.035)\end{array}$ & $\begin{array}{r}-0.061^{\star} \\
(0.036)\end{array}$ & $\begin{array}{r}-0.060^{\star} \\
(0.035)\end{array}$ & $\begin{array}{r}-0.062^{\star} \\
(0.034)\end{array}$ & $\begin{array}{c}-0.105^{\star \star} \\
(0.043)\end{array}$ & $\begin{array}{c}-0.061^{\star} \\
(0.034)\end{array}$ \\
\hline $\begin{array}{l}\text { Cabinet's mean environmental } \\
\text { protection }\end{array}$ & $\begin{array}{r}-0.009 \\
(0.012)\end{array}$ & $\begin{array}{c}0.003 \\
(0.012)\end{array}$ & $\begin{array}{r}-0.0001 \\
(0.011)\end{array}$ & $\begin{array}{r}-0.009 \\
(0.012)\end{array}$ & $\begin{array}{l}-0.019 \\
(0.017)\end{array}$ & $\begin{array}{r}-0.011 \\
(0.011)\end{array}$ \\
\hline $\begin{array}{l}\text { Total greenhouse gas emissions/ } \\
\text { capita }\end{array}$ & $\begin{array}{r}-0.011 \\
(0.027)\end{array}$ & $\begin{array}{r}-0.014 \\
(0.028)\end{array}$ & $\begin{array}{r}-0.019 \\
(0.027)\end{array}$ & $\begin{array}{r}-0.015 \\
(0.027)\end{array}$ & $\begin{array}{r}-0.039 \\
(0.052)\end{array}$ & $\begin{array}{r}-0.019 \\
(0.026)\end{array}$ \\
\hline Green Party in government & $\begin{array}{c}-0.101 \\
(0.088)\end{array}$ & $\begin{array}{c}-0.023 \\
(0.086)\end{array}$ & $\begin{array}{c}-0.006 \\
(0.083)\end{array}$ & $\begin{array}{c}-0.195^{\star \star} \\
(0.092)\end{array}$ & $\begin{array}{c}-0.092 \\
(0.121)\end{array}$ & $\begin{array}{r}-0.182^{\star} \\
(0.096)\end{array}$ \\
\hline $\begin{array}{l}\text { Green Party's environmental } \\
\text { protection }\end{array}$ & $\begin{array}{l}0.006^{\star \star \star} \\
(0.002)\end{array}$ & $\begin{array}{l}0.007^{\star \star \star} \\
(0.002)\end{array}$ & $\begin{array}{l}0.006^{\star \star \star} \\
(0.002)\end{array}$ & $\begin{array}{l}0.008^{\star \star \star} \\
(0.002)\end{array}$ & $\begin{array}{l}0.011^{\star \star \star} \\
(0.003)\end{array}$ & $\begin{array}{l}0.008^{\star \star \star} \\
(0.002)\end{array}$ \\
\hline $\begin{array}{l}\text { Green Party's gross CIP } \\
\text { (yearly mean) }\end{array}$ & $\begin{array}{l}1.034^{\star \star \star} \\
(0.338)\end{array}$ & & & $\begin{array}{l}1.314^{\star \star \star} \\
(0.330)\end{array}$ & $\begin{array}{l}0.883^{\star \star} \\
(0.416)\end{array}$ & $\begin{array}{l}1.283^{\star \star \star} \\
(0.331)\end{array}$ \\
\hline Green Party's polls & & $\begin{array}{c}-1.373 \\
(1.107)\end{array}$ & & $\begin{array}{c}-2.612^{\star \star} \\
(1.092)\end{array}$ & & $\begin{array}{c}-1.785 \\
(1.283)\end{array}$ \\
\hline Green Party's seat share & & & $\begin{array}{c}-2.402 \\
(1.581)\end{array}$ & & & $\begin{array}{r}-1.516 \\
(1.936)\end{array}$ \\
\hline $\begin{array}{l}\text { Share of population worried about } \\
\text { environment }\end{array}$ & & & & & $\begin{array}{r}-0.001 \\
(0.006)\end{array}$ & \\
\hline Constant & $\begin{array}{l}1.640^{\star \star \star} \\
(0.330)\end{array}$ & $\begin{array}{l}1.700^{\star \star \star} \\
(0.294)\end{array}$ & $\begin{array}{l}1.816^{\star \star \star} \\
(0.293)\end{array}$ & $\begin{array}{l}1.907^{\star \star \star} \\
(0.304)\end{array}$ & $\begin{array}{l}2.102^{\star \star \star} \\
(0.594)\end{array}$ & $\begin{array}{l}1.982^{\star \star \star} \\
(0.294)\end{array}$ \\
\hline Observations & 176 & 176 & 176 & 176 & 118 & 176 \\
\hline No. of countries & 9 & 9 & 9 & 9 & 8 & 9 \\
\hline Country fixed-effects & $\checkmark$ & $\checkmark$ & $\checkmark$ & $\checkmark$ & $\checkmark$ & $\checkmark$ \\
\hline Period fixed-effects & $\checkmark$ & $\checkmark$ & $\checkmark$ & $\checkmark$ & $\checkmark$ & $\checkmark$ \\
\hline$R^{2}$ & 0.878 & 0.871 & 0.872 & 0.883 & 0.887 & 0.884 \\
\hline
\end{tabular}

Note: OLS with country and five-year period fixed-effects. Robust standard errors in parentheses. ${ }^{*} p<0.1 ;{ }^{* \star} p<0.05 ;{ }^{* \star *} p<0.01$.

Central to this model is our CIP measure that captures the probability of each country's green party being included in a new government, were elections to be held. We compare its predictive performance against two non-strategic proxies for policy-influence, polls and, less dynamically, seat shares. In all models, whether included separately or in combination with polls and/or seat share or public opinion, our CIP indicator predicts environmental policy stringency. The more that green parties become necessary for prospective coalition formation, the greater the current government's green policy output. These results could suggest that prime minister parties appeal to or try to subvert green parties by tightening environmental policy once they become a viable coalition partner or threat. Even when green parties are in opposition, the PM party has an incentive to court them through demonstrating policy compatibility (strategic positioning). ${ }^{24,25}$ In contrast, the coefficients on the variables for green party polls, seat shares and public opinion - none of which capture the strategic arithmetic of coalition formation-actually host signs suggesting that they reduce environmental stringency and none reaches statistical significance.

\footnotetext{
${ }^{24}$ C.f., Kayser and Rehmert (2020).

${ }^{25}$ See Appendix Table G4 for robustness.
} 


\section{Conclusion}

Political parties are strategic, yet no empirically validated measure exists to capture parties' incentives to trade-off policy against another top priority, government inclusion. Cabinet parties able to credibly threaten to abandon the current government for an alternative, especially if it would exclude a cabinet policy rival, have high credibility and bargaining leverage as shown in our applications. Likewise, opposition parties that are important to the formation of future coalitions have policy leverage as well. By estimating and distributing a measure that captures a quantity central to parties' strategic calculations and by doing so both broadly and dynamically-for all relevant parties in 21 countries over multiple decades at a monthly frequency-we hope that the measures that we provide can enable scholars to investigate a broad swath of new research into a large variety of political and policy-making behavior.

Supplementary material. The supplementary material for this article can be found at https://oi.org/10.1017/psrm.2021.75. To obtain replication material for this article, please visit https://doi.org/10.7910/DVN/GUKPZO

Acknowledgments. We kindly thank Jon Fiva, Evenlyn Hübscher, Rene Lindstädt, Lanny Martin, Anthony McGann, Thomas Sattler and Georg Vanberg for helpful comments. We further thank Lanny Martin, Will Jennings, Christopher Wlezien and Christopher Wratil for sharing data with us. Mark Kayser and Jochen Rehmert gratefully acknowledge support from the German Federal Ministry for Education and Research (BMBF), grant number 01UF1508. Our coalition inclusion data will be made available online at coalition-leverage.org and updated periodically.

\section{References}

Abedi A (2004) Anti-Political Establishment Parties: A Comparative Analysis. London and New York: Routledge.

Abou-Chadi T and Immergut EM (2014) How electoral vulnerability affects pension politics: introducing a concept, measure and empirical application. European Journal of Political Research 53, 269-287.

Abou-Chadi T and Orlowski M (2016) Moderate as necessary: the role of electoral competitiveness and party size in explaining parties' policy shifts. The Journal of Politics 78, 868-881.

Adams J (2012) Causes and electoral consequences of party policy shifts in multiparty elections: theoretical results and empirical evidence. Annual Review of Political Science 15, 401-419.

Ansolabehere Stephen, Snyder James M and Stewart Charles (2001) Candidate positioning in U.S. House Elections. American Journal of Political Science 45, 136-59.

Austen-Smith D and Banks J (1990) Stable governments and the allocation of policy portfolios. The American Political Science Review 84, 891-906.

Banzhaf JF (1964) Weighted voting doesn't work: a mathematical analysis. Rutgers Law Review 19, 317.

Baumgartner FR, Breunig C, Green-Pedersen C, Jones BD, Mortensen PB, Nuytemans M and Walgrave S (2009) Punctuated equilibrium in comparative perspective. American Journal of Political Science 53, 603-620.

Becher M and Christiansen FJ (2015) Dissolution threats and legislative bargaining. American Journal of Political Science 59, 641-655.

Botta E and Kozluk T (2014) "Measuring Environmental Policy Stringency in OECD Countries: a Composite Index Approach.” OECD Economics Department Working Papers (1177).

Cutler J, De Marchi S, Gallop M, Hollenbach FM, Laver M and Orlowski M (2016) Cabinet formation and portfolio distribution in european multiparty systems. British Journal of Political Science 46(1), 31-43.

Döring H and Manow P (2016) "Parliament and government composition database (ParlGov)." An infrastructure for empirical information on parties, elections and governments in modern democracies. Development version. http://www.parlgov. org/.

Druckman JN and Jacobs LR (2006) Lumpers and splitters: the public opinion information that politicians collect and use. International Journal of Public Opinion Quarterly 70, 453-476.

Durr RH (1993) What moves policy sentiment?. American Political Science Review 87, 158-72.

Gamson WA (1961) A theory of coalition formation. American Sociological Review 26, 373-382.

Glasgow G and Golder SN (2015) A new approach to the study of parties entering government. British Journal of Political Science 45, 739-754.

Glasgow G, Golder M and Golder SN (2012) New empirical strategies for the study of parliamentary government formation. Political Analysis 20, 248-270.

Hecock RD (2006) Electoral competition, globalization, and subnational education spending in Mexico, 1999-2004. American Journal of Political Science 50, 950-61. 
Huber JD and Powell BG (1994) Congruence between citizens and policymakers in two visions of liberal democracy. World Politics 46, 291-326.

Jennings W and Wlezien C (2016) The timeline of elections: a comparative perspective. American Journal of Political Science 60, 219-233.

Kayser MA and Rehmert J (2020) Coalition prospects and policy change: an application to the environment. Legislative Studies Quarterly 35, 851-880.

Kayser MA and Lindstädt R (2015) A cross-national measure of electoral competitiveness. Political Analysis 23, $242-253$.

Kim D-H and Loewenberg G (2005) The role of parliamentary committees in coalition governments: keeping tabs on coalition partners in the German Bundestag. Comparative Political Studies 38, 1104-1129.

Klemmensen R and Hobolt SB (2005) Responsive government? Public opinion and government policy preferences in Britain and Denmark. Political Studies 53, 379-402.

Klüver H and Bäck H (2019) Coalition agreements, issue coverage and cabinet governance. Comparative Political Studies 52, 1995-2031.

König T, Marbach M and Osnabrügge M (2013) Estimating party positions across countries and time-a dynamic latent variable model for manifesto data. Political Analysis 21, 468-491.

Laver M and Shepsle KA (1996) Making and Breaking Governments: cabinets and Legislatures in Parliamentary Democracies. Cambridge and New York: Cambridge University Press.

Lowe Will, Benoit Kenneth, Mikhaylov Slava and Laver Michael (2011) Scaling policy preferences from coded political texts. Legislative Studies Quarterly 36, 123-155.

Lupia A and Strøm K (1995) Coalition termination and the strategic timing of parliamentary elections. American Political Science Review 89, 648-665.

Martin LW and Vanberg G (2011) Parliaments and Coalitions: The Role of Legislative Institutions in Multiparty Governance. Oxford and New York: OUP Oxford.

Martin LW and Vanberg G (2015) Coalition formation and policymaking in parliamentary democracies. In Gandhi J and Ruiz-Rufino R (eds). Routledge Handbook of Comparative Political Institutions. London: Routledge, chapter 13, pp. 181194.

Martin LW and Vanberg G (2020) What you see is not always what you get: bargaining before an audience under multiparty government. American Political Science Review 114, 1138-1154.

Martin LW and Stevenson RT (2001) Government formation in parliamentary democracies. American Journal of Political Science 45, 33-50.

Martin LW and Stevenson RT (2010) The conditional impact of incumbency on government formation. American Political Science Review 104, 503-518.

Page BI and Shapiro RY (1983) Effects of public opinion on policy. American Political Science Review 77, 175-190.

Penrose LS (1946) The elementary statistics of majority voting. Journal of the Royal Statistical Society 109, 53-57.

Powell GB (2009) The ideological congruence controversy: the impact of alternative measures, data, and time periods on the effects of election rules. Comparative Political Studies 42, 1475-97.

Shapley LS and Shubik M (1954) A method for evaluating the distribution of power in a committee system. American Political Science Review 48, 787-792.

Solé-Ollé A (2006) The effects of party competition on budget outcomes: empirical evidence from local governments in Spain. Public Choice 126, 145-76.

Soroka SN and Wlezien C (2010) Degrees of Democracy: Politics, Public Opinion, and Policy. Cambridge and New York: Cambridge University Press.

Stimson James A, MacKuen Michael B and Erikson Robert S (1995) Dynamic representation. American Political Science Review 89, 543-565.

Thies MF (2001) Keeping tabs on partners: the logic of delegation in coalition governments. American Journal of Political Science 45, 580-598.

Volkens A, Lehmann P, Mathhieß T, Merz N, Regel S and Werner A (2015) "The Manifesto Data Collection. Manifesto Project (MRG/CMP/MARPOR). Berlin: Wissenschaftszentrum Berlin für Sozialforschung (WZB). Version 2015a.” https:// manifesto-project.wzb.eu/.

Wagner A (2017) A micro perspective on political competition: electoral availability in the European electorates. Acta Politica 52, 502-520.

Wlezien C (1995) The public as thermostat: dynamics of preferences for spending. American Journal of Political Science 39, 981-1000.

Wlezien C and Soroka SN (2012) Political institutions and the opinion-policy link. West European Politics 35, 1407-1432.

Wlezien C and Soroka SN (2016) Public Opinion and Public Policy. In Oxford Research Encyclopedia of Politics. Retrieved 8 Jan. 2020, from https://oxfordre.com/politics/view/10.1093/acrefore/9780190228637.001.0001/acrefore-9780190228637-e-74.

Cite this article: Kayser MA, Orlowski M, Rehmert J (2023). Coalition inclusion probabilities: a party-strategic measure for predicting policy and politics. Political Science Research and Methods 11, 328-346. https://doi.org/10.1017/psrm.2021.75 